\title{
Aging Cell Culture - Genetic and Metabolic Effects of Passage Number on Zebrafish Z3 Cells
}

\author{
Maja Šrut Bettina Peer Birgit Fiechtner Margit Egg Adolf Michael Sandbichler \\ Martina Höckner
}

University of Innsbruck, Institute of Zoology, Center for Molecular Biosciences Innsbruck, Innsbruck, Austria

\section{Key Words}

Cell line $\cdot$ Passage number $•$ Zebrafish $•$ Aging $・$ Metabolism • Senescence $・$ DNA damage • Redox state

\begin{abstract}
Background/Aims: Since cell lines are cultured and extensively used in a variety of different research disciplines, we determined the effects of passage numbers on a commonly used embryonic zebrafish cell line (Z3). Methods: Senescence markers, DNA damage, the redox state, gene expression, and metabolic parameters have been investigated in young (passage 5) up to very old (passage 40 and higher) cells. Results: Besides increasing DNA damage, we also found elevated metabolic capacity and a shift to a more reduced cellular redox state in the cells. Interestingly, several parameters showed a non-linear course regarding the passage number or cell age, so that for example young and mid-aged cells appeared to cluster with very old rather than with old cells. Conclusion: This study illustrates the importance of passage number and suggests pre-testing specific parameters to assure the generation of accurate and reproducible data.

\section{Introduction}

When cells of the zebrafish embryonic fibroblast line Z3 are grown to $70-80 \%$ confluency, they are split in a ratio of 1:7. This process, known as passaging, can also be related to the chronological age of cells. Cells which are grown in a monolayer do not reflect the conditions that prevail in tissues, and the passage number or the chronological age appear to induce changes in cell physiology. The latter poses a high risk of misinterpreting data, which often leads to the lack of generating reproducible data.

Passage numbers have been shown to reveal differences for example in rabies testing [1], in resistance to $\mathrm{H}_{2} \mathrm{O}_{2}$-induced apoptosis [2], in cell doubling time and osteogenic characteristics 


\section{Cellular Physiology Cell Physiol Biochem 2022;56:50-65 \\ \begin{tabular}{l|l} 
DOI: 10.33594/000000494 & 2022 The Author(s). Published by
\end{tabular} \\ \begin{tabular}{l|l} 
Published online: 9 February 2022 & Cell Physiol Biochem Press GmbH\&Co. KG \\
\hline
\end{tabular} \\ Šrut et al.: Aging Cell Culture}

in D1 cells [3], in reduced gene expression and tumorigenic properties from Uveal Melanoma Primary Tumors-derived cell lines [4], in Insulin-Degrading Enzyme activity [5] as well as in P-glycoprotein expression [6] both in Caco-2 cells. Hughes and colleagues reported already on contradictory results in a review article on Caco-2 cells in 2007 [7]. Karyotype comparison of two cell lines (MCF-7 and Ishikawa) revealed chromosomal aberrations with increasing passage number depending on culture conditions [8]. Also, the emergence of an aberrant X chromosome in high passage numbers of human embryonic stem cells (hES) was demonstrated [9]. Further passage-related effects like impaired mitochondrial function have been shown in hES [10]. hES were even affected by different passaging methods, such as enzymatic versus nonenzymatic dissociation of cell clusters, the latter of which appeared to induce chromosomal aberrations [11]. Increased passage numbers of HT29 cells were reported to induce a decrease in cell proliferation and their ability to migrate, and led to altered cell cycle distributions [12]. Hence, putative differences in passage numbers that are probably cell-line-specific have to be excluded before starting new experiments.

Ageing has been defined as "the time-related deterioration of the physiological functions necessary for survival and fertility" [13] and is linked to senescence, which was originally referred to as the replicative limit of cell cultures. Recently, senescence was defined as "state of stress-induced irreversible proliferative arrest and resistance to both mitogenic and oncogenic stimuli" [14]. Senescence has widely been used to determine ageing in cell cultures. However, even before senescence and replicative arrest occurs, the passage number of dividing cells has a great impact on several genetic and physiological parameters.

We examined the frequently used embryonic zebrafish cell line Z3 to determine putative changes up to passage number 50, which equals in the case of the Z3 cell line 50 weeks of culturing. Zebrafish cells are derived from dispersed zebrafish embryos that are cultured until a stable cell cluster forms, which is able to survive and continues to proliferate [15, 16]. Those very early passage numbers are then cryopreserved and can be shared within the scientific community. Senescence markers, DNA damage, and metabolic measurements have been used to evaluate the effect of passage numbers and eventually cell age.

\section{Materials and Methods}

\section{Culturing of Z3 cells}

The Z3 zebrafish cell line was originally established in 2001 from $24 \mathrm{~h}$-old embryos to investigate the light-dependent gene activation of their circadian oscillator [15]. Cells were cultured in a Peltiercooled incubator (Memmert, Germany) at $25^{\circ} \mathrm{C}$ under normal air atmosphere in Leibovitz L15 media supplemented with $15 \% \mathrm{v} / \mathrm{v}$ fetal bovine serum, penicillin and streptomycin (both $1 \%$ ), gentamycin $(0.1 \%)$ and L-glutamine (2 $\mathrm{mM}$ ) (all from Thermo Fisher Scientific, Waltham, Massachusetts, United States). Cells were split once a week, which increased the passage number weekly by one. Samples were taken as described in the respective methodical section.

\section{Doubling time}

Z3 cells were seeded (5000 cells per well) and cultured in 96-well plates. The cell number of each passage was measured 24, 48, 72, and 96 hours after seeding using Hoechst 33342 (Thermo Fisher Scientific, Waltham, Massachusetts, United States). The mean of four replicates of each time point was used to calculate the doubling time.

\section{Beta-gal assay}

Cells were seeded on a cover slip, which was placed into a petri dish and left overnight. The next day, the medium was removed and $2 \mathrm{ml}$ fixation buffer was added and left for $4 \mathrm{~min}$ at room temperature. The liquid was removed followed by three washing steps with $1 \times$ PBS. Then $2 \mathrm{ml}$ of the staining solution (5mM $\mathrm{K}_{4}\left[\mathrm{Fe}(\mathrm{CN})_{6}\right], 5 \mathrm{mM} \mathrm{K}_{3}\left[\mathrm{Fe}(\mathrm{CN})_{6}\right], 40 \mathrm{mM}$ Citric acid, $12 \mathrm{mM} \mathrm{Na}_{2} \mathrm{HPO}_{4}, 150 \mathrm{mM} \mathrm{NaCl}, 2 \mathrm{mM} \mathrm{MgCl}_{2}$ in a total of $19 \mathrm{ml}, \mathrm{pH}$ 5.8; freshly add $1 \mathrm{ml}$ of $\mathrm{x}$-Gal solution (20mg/ml x -Gal in DMF)) was added and incubated in 


\section{Cellular Physiology Cell Physiol Biochem 2022;56:50-65 \\ \begin{tabular}{l|l|l}
\hline DOI: 10.33594/000000494 & ( 2022 The Author(s). Published by
\end{tabular} \\ and BiOChemistry Published online: 9 February 2022 Cell Physiol Biochem Press GmbH\&Co. KG \\ Šrut et al.: Aging Cell Culture}

the dark at $37^{\circ} \mathrm{C}$ for $22 \mathrm{~h}$. The reaction was stopped using TBS-T, rinsed with distilled water and mounted using Faramount (Agilent). Upon microscopic evaluation of the slides it became obvious that we can clearly distinguish three groups of cells. The group of negative cells did not show any staining. The second group of stage 1 cells showed a slight blue staining, whereas stage 2 cells revealed a dark blue staining. Image acquisition and analysis were performed in a blinded fashion. For each passage four slides were prepared and five images from each slide were taken. A minimum of 100 cells per image were counted and used for analysis (\% cells of the respective group of total cell number).

\section{Quantitative RealTime PCR ( $q P C R$ )}

Media was removed from the petri dish, TRIzol (Thermo Fisher Scientific, Waltham, Massachusetts, United States) was added and cells were removed using a cell scraper. RNA extraction using TRIzol was accomplished according to the user manual. RevertAidHplus and random hexamer primers were then used to transcribe 450 ng RNA into cDNA. RNA concentration was measured using Ribogreen in triplicates on a plate reader (Victor4, Perkin Elmer, Waltham, Massachusetts, United States). SYBRGreen (Thermo Fisher Scientific, Waltham, Massachusetts, United States) was used for absolute quantification of copy numbers using a standard curve. PCR efficiency was at $82 \%$. The primer concentrations used were previously determined by testing different primer concentrations, namely $0.5 \mu \mathrm{M}, 3 \mu \mathrm{M}$ and $9 \mu \mathrm{M}$, in PCR reactions. We then selected for the most effective combination, which results in the highest amount of amplicon without any unspecific products.

\section{Western Blot}

Stored proteins were kept at $-80^{\circ} \mathrm{C}$ in $2 \mathrm{x}$ Laemmli buffer and were heated for $5 \mathrm{~min}$ at $95^{\circ} \mathrm{C}$, centrifuged, and the supernatant was transferred to a new tube. Concentration was measured using the NanoDrop (Thermo Fisher Scientific, Waltham, Massachusetts, United States). $20 \mu$ g whole protein extracts were separated on a $12 \%$ precast gel (Bio-Rad, Hercules, California, United States) and transferred to a PVDF membrane (Bio-Rad, Hercules, California, United States) using a semidry blot system (Bio-Rad, Hercules, California, United States) with standard settings. The membrane was blocked with $5 \%$ milk powder in TBS-T for one hour at room temperature. The membrane was then cut at $70 \mathrm{kD}$ and used for incubation with the Hif1 (1:1000; [17]) and catalase (1:5000; Anti-CATALASE (RABBIT) Antibody - 100-4151, Rockland Inc., Limerick, Pennsylvania, USA) antibodies. The membranes were then left overnight at $4^{\circ} \mathrm{C}$ in blocking buffer, washed with TBS-T three times for $10 \mathrm{~min}$ and incubated with the second antibody (pox anti rabbit) for one hour at room temperature in blocking buffer. Three washing steps with TBS-T were followed with detection using ECL using the chemidoc (Bio-Rad, Hercules, California, United States). The same procedure was applied for Hif3 $(1: 5000,[17])$.

\section{Comet assay}

The alkaline comet assay was performed as previously described [18], with slight modifications. $50 \mu \mathrm{l}$ aliquots of cell suspension (200 cells/ $\mu$ l) and 0.5\% low melting point (LMP, Sigma-Aldrich) agarose were mixed and placed on $1 \%$ normal agarose precoated microscope slides. After solidifying at $0^{\circ} \mathrm{C}$, a third layer of $0.5 \%$ LMP agarose was added and left to solidify. Prepared slides were placed in petri dishes and treated with $200 \mathrm{ml}$ of phosphate buffer saline (PBS) containing serial dilutions of hydrogen peroxide $\left(\mathrm{H}_{2} \mathrm{O}_{2}\right.$, 1,10 and $100 \mu \mathrm{M}$ ) for $10 \mathrm{~min}$ at room temperature. Cells exposed only to pure PBS were used as a control. Exposure was carried out in triplicates. After the exposure, slides were rinsed with PBS and subsequently placed in lysing buffer (2.5 M NaCl, 100 mM EDTA, 10 mM Tris-HCl, 10\% DMSO, 1\% Triton X-100, pH 10). After lysing for $1 \mathrm{~h}$ at $4{ }^{\circ} \mathrm{C}$, slides were rinsed with redistilled water, placed on the horizontal gel box and covered with the cold alkaline buffer $(0.3 \mathrm{M} \mathrm{NaOH}, 1 \mathrm{mM}$ EDTA, $\mathrm{pH}>13)$ for $20 \mathrm{~min}$. Electrophoresis was run in the same buffer at $0.4 \mathrm{Vcm}^{-1}$ and $300 \mathrm{~mA}$ for $30 \mathrm{~min}$ at $4^{\circ} \mathrm{C}$. After neutralization $(0.4 \mathrm{M}$ Tris- $\mathrm{HCl}, \mathrm{pH}$ 7.5), slides were fixed in methanol:acetic acid (3:1) for $5 \mathrm{~min}$ and stored in the dark at room temperature. Prior to examination, slides were rehydrated and stained with $4 \%$ GelRedTM (Biotium, USA). On every slide at least 100 nuclei were examined using an Axiovert $100 \mathrm{M}$ microscope (Zeiss, Germany). The extent of DNA migration was determined as percentage of DNA in tail (\% tDNA) using the image analysis system CASP [19]. Due to the software's technical limitations in determining the percentage of DNA damage in highly damaged cells (where almost all DNA is in tail), those cells were manually assigned a value of $98 \%$ tDNA. 


\section{Cellular Physiology Cell Physiol Biochem 2022;56:50-65

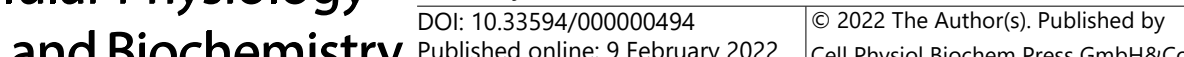 \\ Published online: 9 February 2022 Cell Physiol Biochem Press GmbH\&Co. KG \\ Šrut et al:: Aging Cell Culture}

Mean values of the tDNA damage for each treatment group were calculated and data are presented as mean and corresponding standard deviation (SD). Due to non-normally distributed data, statistical analysis was performed using the Kruskal Wallis non-parametric test, followed by a pairwise Wilcoxon test (R Studio, Version 1.0.143). Level of significance reported: $\mathrm{p} \leq 0.05$.

Seahorse XFp extracellular flux analyzer measurements

Oxygen consumption rate (OCR) and extracellular acidification rate (ECAR) in Z3 cells of different passage numbers were measured with a Seahorse XFp Analyzer (Agilent, USA). Cells were seeded at a density of $10^{5}$ cells per well and were cultured overnight in growth medium before changing the media to DMEM containing two mM L-glutamine and, depending on the analysis, five $\mathrm{mM}$ glucose and one $\mathrm{mM}$ pyruvate. We used two commercial Seahorse XFp kits for characterizing respiratory (Mitochondria stress test, Agilent, USA) or glycolytic activity (Glycolysis stress test, Agilent, USA) and followed the instructions provided by the manufacturer. Chemical inhibitors were prepared as ten times stock in the same media and deposited in the injection ports of the sensor cartridges. The seahorse device was placed in a climate chamber and measurement temperature was set to $26^{\circ} \mathrm{C}$. XFp data was analyzed in Seahorse Wave software and exported to Excel (Microsoft, USA) for further analysis. Rate data was normalized to the last three measurement points before chemicals were injected.

\section{Lactate and Pyruvate quantification}

Sampling: From each passage, cells were rinsed with ice cold PBS. After addition of $850 \mu \mathrm{l}$ TE buffer $(\mathrm{pH} 7)$, cells were removed from the petri dish using a cell scraper and shock frozen in liquid nitrogen. After thoroughly mixing the homogenate and centrifugation at $4^{\circ} \mathrm{C}$ for $1 \mathrm{~min}$ at $5000 \mathrm{rcf}$, the supernatant was applied to spin filters with a cut off at $10 \mathrm{kDa}$ and centrifuged at room temperature for $15 \mathrm{~min}$ at $14000 \mathrm{rcf}$. The flow through was collected and stored at $-80^{\circ} \mathrm{C}$. The filter was then turned upside down and placed into a fresh tube and centrifuged at room temperature for $2 \mathrm{~min}$ at $1000 \mathrm{rcf}$. The flow through, herein referred to as concentrate, was stored at $-80^{\circ} \mathrm{C}$ and used for measuring the protein content, which was used for data normalization.

The filtrates were thawed and measured in triplicates applying a standard curve. The pyruvate and lactate standard included the following concentrations: $1 \mathrm{mM}, 0.5 \mathrm{mM}, 0.25 \mathrm{mM}, 0.125 \mathrm{mM} .10 \mu \mathrm{l} \mathrm{sample}, 10 \mu \mathrm{l}$ distilled water and $15 \mathrm{~min}$ before the measurement $100 \mu \mathrm{l} \mathrm{TEN} \mathrm{buffer}+\mathrm{LDH}(3 \mathrm{U} / \mathrm{ml})(0.05 \mathrm{M}$ Tris $+5 \mathrm{mM}$ EDTA, $0.15 \mathrm{mM} \mathrm{NADH}, \mathrm{pH}$ 7.4) was added and the samples were incubated in the dark at room temperature.

For measuring lactate, $10 \mu \mathrm{l}$ sample, $10 \mu \mathrm{l}$ distilled water and $200 \mu \mathrm{l}$ lactate buffer $(0.5 \mathrm{M}$ glycine, $0.4 \mathrm{M}$ hydrazine sulfate) were combined. $30 \mathrm{~min}$ before the measurement, $25 \mu \mathrm{L}$-LDH (1:200) were added and the samples were kept at room temperature in the dark until start of the measurement.

The protein concentration was determined from the concentrates in triplicates using the Nano Drop (Thermo Fisher Scientific, Waltham, Massachusetts, United States) and used for data normalization.

\section{Statistical analysis}

Data were analysed using GraphPad Prism 9.2.0. Normality was tested applying Shapiro-Wilk test. Significant differences were detected with One-Way Anova and Tukey's multiple comparisons test or KruskalWallis test and Dunn's multiple comparisons test for not normally distributed data. Group differences of the growth rate was analysed with the Mann Whitney test. Comet assay data and multidimensional scaling analysis (MDS) were performed in RStudio Version 1.3.1073 (R Core Team, 2020). Significance of comet assay data was tested with Kruskal Wallis test using script "kruskal.test" followed by script "pairwise.wilcox. test" using bonferroni correction, to get the pairwise comparisons between groups. MDS was performed using script "cmdscale" [20]. 


\section{Results}

We examined physiological and genetic effects of cell passage numbers, which might relate to aging in cell cultures in a zebrafish embryonic fibroblast cell line (Z3).

\section{Growth rate}

We determined the doubling time of passage numbers 4-6, 15-18, 33-36, and 46-49, which we called young, mid age, old and very old, respectively. A significant difference was detected between the youngest and oldest group for which the doubling time decreased (Fig. 1). We did not observe cell cycle arrest in any cell passage up to 49. Especially the group of passage 33-36 showed high variability in doubling time (Fig. 1).

\section{Beta galactosidase (SAbeta-gal) activity}

The senescence-associated beta galactosidase (SAbeta-gal) activity, a marker for cellular senescence, showed a significant increase in higher passages. Staining intensity was categorized as either negative, light blue (stage 1) or dark blue (stage 2). We observed an increase of stage 1 cells at passage 31 with elevated levels until passage 40 . Hardly any stage 2 cells were detected (Fig. 2A), which might confirm the previous results that no proliferative arrest was determined. We therefore conclude that no senescent cells were present in either of the passages.

Fig. 1. Z3 cell doubling time. The growth rate of several passages (four biological replicates) was measured using Hoechst 33342 nuclear staining. Grouping of very old compared to young cells showed a significantly lower doubling time.

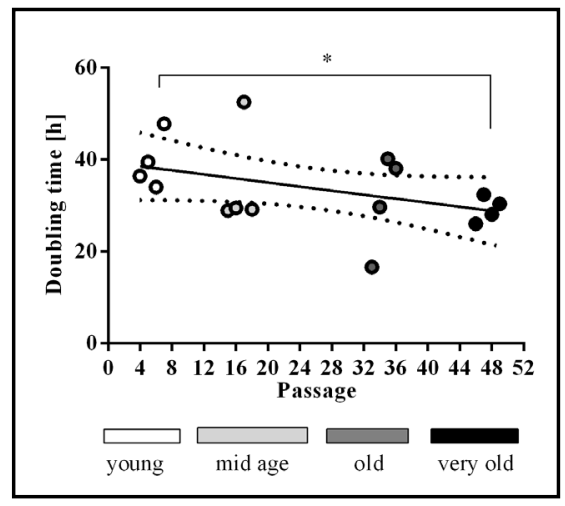

Fig. 2. Cellular senescence. (A) beta galactosidase (SAbeta-gal) activity assay, which revealed three cell stages according to their staining intensity (shown in panel). Old cells show significantly increased stage 1 cells. At least 2000 cells were analysed per passage. (B) Prior to the increase of beta-gal activity, p53 transcription levels were significantly higher in mid age cells. $n=3$. Error bars denote mean values \pm SEM.

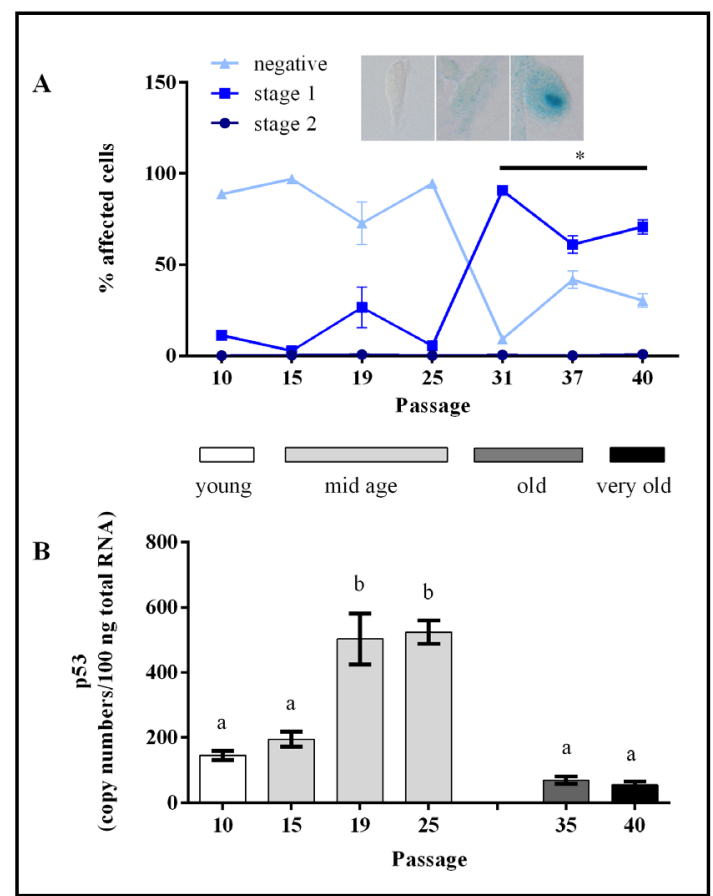




\section{Cellular Physiology Cell Physiol Biochem 2022;56:50-65 \\ \begin{tabular}{l|l|l} 
DOI: 10.33594/000000494 & $(022$ The Author(s). Published by
\end{tabular} \\ Published online: 9 February 2022 Cell Physiol Biochem Press GmbH\&Co. KG \\ Šrut et al.: Aging Cell Culture}

P53 gene expression

p53 gene expression, which can be associated with senescence, showed a significant increase in passages 19 and 25, which in passages 35, and 40 again decreased (Fig. 2B).

\section{DNA damage}

The results of the Comet assay showed a significant difference in the basal level of DNA damage as well as a difference in cell response to oxidative stress as result of cell age. Control cells at passage 40 have significantly higher levels of DNA damage compared to cells at passage 5 and 20 (Fig. 3). The exposure to $\mathrm{H}_{2} \mathrm{O}_{2}$ resulted in a dose response effect on DNA damage - cells with higher passage, in general, accumulated a higher percentage of DNA damage (Fig. 3). The only exception was evident for passage 40 treated with $100 \mu \mathrm{M} \mathrm{H}_{2} \mathrm{O}_{2}$.

\section{Pyruvate, Lactate and the cellular redox state}

Lactate was increased in passages 31 and 36 and decreased in passages 40 and 45 (Fig. 4A). Pyruvate decreased significantly in aging cells (Fig. 4B). The redox status of the cells was determined using the NAD+:NADH ratio (pyruvate:lactate) [21, 22], which revealed a decrease meaning that with higher passage numbers the cells are going towards a reduced redox state (Fig. 4C). Catalase, which catalyzes the degradation of hydrogen peroxide to water and oxygen, did not show any changes in protein abundance in different cell passages (Fig. 5).

\section{Extracellular Flux Measurements}

Oxygen consumption rate (OCR) and extracellular acidification rates (ECAR) were measured in mid age, old and very old passage groups. Glycolytic function was determined by applying the glycolysis stress test (Agilent, Fig. 6A). Basal glycolysis did not change between different passages. Non-glycolytic acidification was significantly increased in passage 46 (very old) compared to passage 33 (old) (Fig. 6B). The glycolytic reserve increased in passage 46 (Fig. 6C). The parameters are explained in more detail in Table 1 as stated in the glycolysis stress test (and mitochondrial stress test) user manual provided by the kit manufacturer (Agilent).

A mitochondrial stress test (Agilent) revealed that non-mitochondrial OCR, basal- and maximum respiration as well as ATP production did not change (Fig. 7A-B). However, proton leak decreased in higher passages and coupling efficiency as well as spare capacity increased significantly (Fig. 7B-C).

Regarding glycolytic function and mitochondrial parameters, we can assume that the metabolic potential (glycolytic reserve and mitochondrial spare capacity) of cells from higher passages increased.

Finally, the stress response of OCR and ECAR to inhibition with FCCP and Oligomycin can be plotted against each other to depict the energy phenotype of the cells (Fig. 8) and to investigate metabolic switching. Under FCCP and Oligomycin inhibition OCR as well as ECAR are at maximum due to mitochondrial uncoupling and glycolysis-restricted ATP production, respectively. Interestingly, all three age groups upregulate their ECAR whereas only old and very old age groups also respond with a higher OCR to the stress. Table 2 gives a summary and overview of all the results. 
Fig. 3. Comet assay on zebrafish Z3 cells at different passages $(5,20$ and 40, corresponding to groups young, mid age and very old, respectively), in control cells and cells exposed to 1, 10 and $100 \mu \mathrm{M} \mathrm{H}_{2} \mathrm{O}_{2}$. Error bars denote mean \pm SEM; $n=300$ for each treatment.

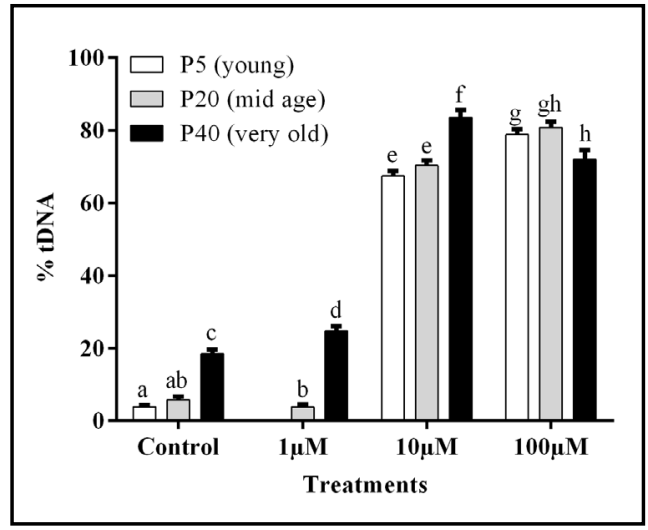

Fig. 4. Redox status calculated from the pyruvate:lactate ratio of $\mathrm{Z3}$ cells in different cell passages. (A) Lactate, significances are as follows: 5 vs. $31^{*}, 9$ vs. $31^{*}, 19$ vs. $31^{* *}$, 31 vs. $45^{* *}, 31$ vs. $50^{* *}, 36$ vs. $45^{*}$ (B) Pyruvate, significances are as follows: 5 vs. $19^{* * * *}, 5$ vs. $25^{* * * *}, 5$ vs. $31^{*}$, 5 vs. $36^{* * * *}, 5$ vs. $40^{* * * *}, 5$ vs. $45^{* * * *}, 5$ vs. $50^{* * * *}, 9$ vs. $19^{* *}, 9$ vs. $25^{* *}, 9$ vs. $36^{* *}, 9$ vs. $40^{* * *}, 9$ vs. $45^{* * * *}, 9$ vs. $50^{* *}, 15$ vs. $19^{* *}, 15$ vs. $25^{* *}, 15$ vs. $36^{* *}, 15$ vs. $40^{* *}$, 15 vs. $45^{* * * *}, 15$ vs. $50^{* *}, 31$ vs. $45^{* *} .{ }^{*} \mathrm{p}<0.05$, ${ }^{* *} \mathrm{p}<0.001$, $* * * * \mathrm{p}<0.0001$. (C) With increasing age, cells are reaching a more reduced cellular redox state as shown from the $\mathrm{NAD}+\mathrm{NADH}$ ratio. Error bars denote mean values $\pm \mathrm{SEM}$; $\mathrm{n}=4$.

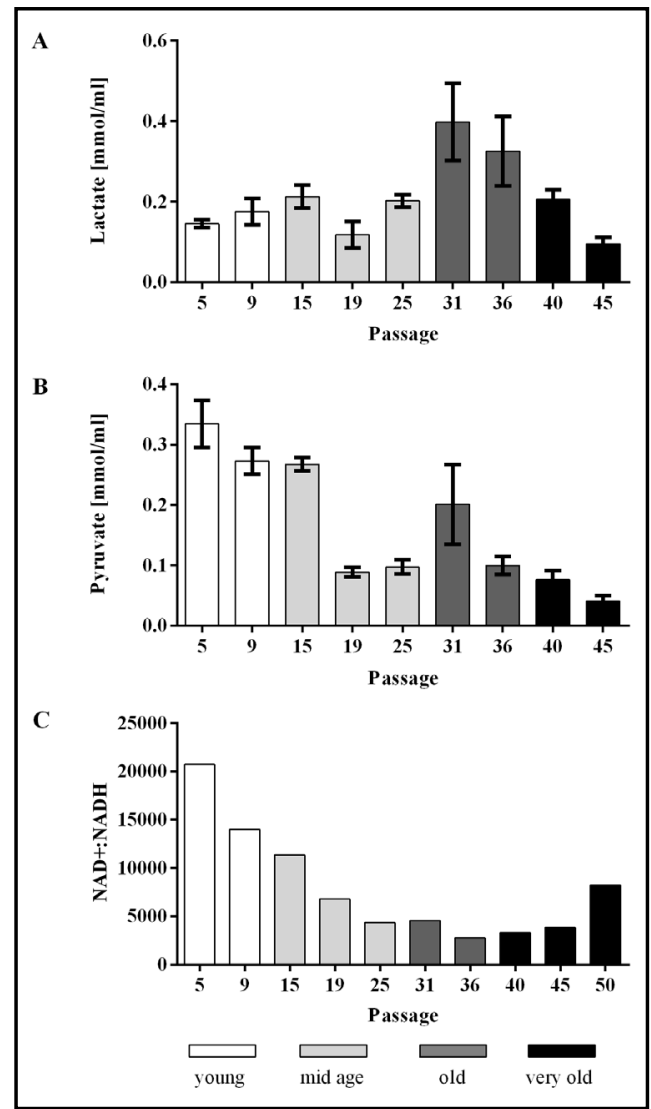

Fig. 5. Catalase protein expression did not change significantly in different cell passages. Error bars denote mean values $\pm S E M ; n=4$.

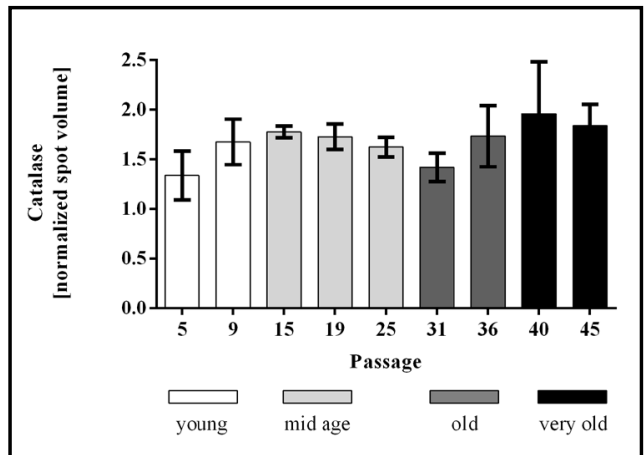




\section{Cellular Physiology Cell Physiol Biochem 2022;56:50-65 \begin{tabular}{ll|l} 
and Biochemistry 10.33594/000000494 & P 2022 The Author(s). Published by \\
Published online: 9 February 2022 & Cell Physiol Biochem Press GmbH\&Co. KG
\end{tabular}

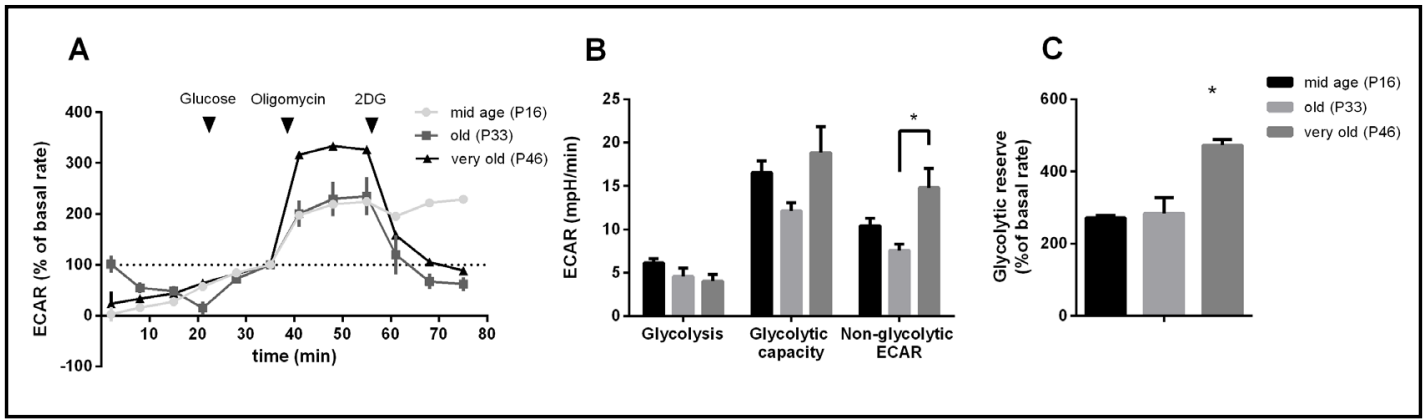

Fig. 6. Glycolysis stress test. (A) Time course of ECAR of mid age, old, and very old cells, while adding glucose and the indicated inhibitors. The rate signal is shown normalized to timepoint 6 where glucose was present. (B) Measurement of ECAR enables the determination of glycolysis, glycolytic capacity, and nonglycolytic ECAR as well as the glycolytic reserve (C). Error bars denote mean values \pm SEM; $n=3$.

Table 1. Parameters calculated from extracellular flux measurements and their definition

\begin{tabular}{|c|c|c|}
\hline Parameter & Definition & Mathematical operation \\
\hline \multicolumn{3}{|c|}{ Glycolysis stress test } \\
\hline Glycolysis & $\begin{array}{l}\text { The process of converting glucose to pyruvate. The XF Glycolysis Stress Test } \\
\text { presents the measure of glycolysis as the ECAR rate reached by a given cell after } \\
\text { the addition of saturating amounts of glucose. }\end{array}$ & $\begin{array}{l}\text { (Maximum rate measurement before } \\
\text { Oligomycin injection) - (Last rate } \\
\text { measurement before Glucose injection) }\end{array}$ \\
\hline $\begin{array}{l}\text { Glycolytic } \\
\text { capacity }\end{array}$ & $\begin{array}{l}\text { This measurement is the maximum ECAR rate reached by a cell following the } \\
\text { addition of oligomycin, effectively shutting down oxidative phosphorylation and } \\
\text { driving the cell to use glycolysis to its maximum capacity. }\end{array}$ & $\begin{array}{l}\text { (Maximum rate measurement after } \\
\text { Oligomycin injection) - (Last rate } \\
\text { measurement before Glucose injection) }\end{array}$ \\
\hline $\begin{array}{l}\text { Glycolytic } \\
\text { reserve }\end{array}$ & $\begin{array}{l}\text { This measure indicates the capability of a cell to respond to an energetic demand } \\
\text { as well as how close the glycolytic function is to the cell's theoretical maximum. }\end{array}$ & (Glycolytic Capacity) - (Glycolysis) \\
\hline $\begin{array}{l}\text { Non-glycolytic } \\
\text { acidification }\end{array}$ & $\begin{array}{l}\text { This parameter measures other sources of extracellular acidification that are not } \\
\text { attributed to glycolysis. }\end{array}$ & $\begin{array}{l}\text { Last rate measurement prior to glucose } \\
\text { injection }\end{array}$ \\
\hline \multicolumn{3}{|c|}{ Mitochondrial stress test } \\
\hline $\begin{array}{l}\text { Basal } \\
\text { respiration }\end{array}$ & $\begin{array}{l}\text { Oxygen consumption used to meet cellular ATP demand resulting from } \\
\text { mitochondrial proton leak. Shows energetic demand of the cell under baseline } \\
\text { conditions. }\end{array}$ & $\begin{array}{l}\text { (Last rate measurement before first } \\
\text { injection) - (Non-Mitochondrial Respiration } \\
\text { Rate) }\end{array}$ \\
\hline $\begin{array}{l}\text { ATP } \\
\text { Production }\end{array}$ & $\begin{array}{l}\text { The decrease in oxygen consumption rate upon injection of the ATP synthase } \\
\text { inhibitor oligomycin represents the portion of basal respiration that was being } \\
\text { used to drive ATP production. Shows ATP produced by the mitochondria that } \\
\text { contributes to meeting the energetic needs of the cell. }\end{array}$ & $\begin{array}{l}\text { (Last rate measurement before Oligomycin } \\
\text { injection) - (Minimum rate measurement } \\
\text { after Oligomycin injection) }\end{array}$ \\
\hline $\begin{array}{l}\mathrm{H}+(\text { Proton }) \\
\text { leak }\end{array}$ & $\begin{array}{l}\text { Remaining basal respiration not coupled to ATP production. Proton leak can be a } \\
\text { sign of mitochondrial damage or can be used as a mechanism to regulate the } \\
\text { mitochondrial ATP production. }\end{array}$ & $\begin{array}{l}\text { (Minimum rate measurement after } \\
\text { Oligomycin injection) - (Non-Mitochondrial } \\
\text { Respiration) }\end{array}$ \\
\hline $\begin{array}{l}\text { Maximal } \\
\text { respiration }\end{array}$ & $\begin{array}{l}\text { The maximal oxygen consumption rate attained by adding the uncoupler FCCP. } \\
\text { FCCP mimics a physiological "energy demand" by stimulating the respiratory } \\
\text { chain to operate at maximum capacity, which causes rapid oxidation of } \\
\text { substrates (sugars, fats, and amino acids) to meet this metabolic challenge. } \\
\text { Shows the maximum rate of respiration that the cell can achieve. }\end{array}$ & $\begin{array}{l}\text { (Maximum rate measurement after FCCP } \\
\text { injection) - (Non-Mitochondrial Respiration) }\end{array}$ \\
\hline $\begin{array}{l}\text { Spare } \\
\text { respiratory } \\
\text { capacity }\end{array}$ & $\begin{array}{l}\text { This measurement indicates the capability of the cell to respond to an energetic } \\
\text { demand as well as how closely the cell is to respire to its theoretical maximum. } \\
\text { The cell's ability to respond to demand can be an indicator of cell fitness or } \\
\text { flexibility. }\end{array}$ & (Maximal Respiration) - (Basal Respiration) \\
\hline $\begin{array}{l}\text { Non- } \\
\text { mitochondrial } \\
\text { respiration }\end{array}$ & $\begin{array}{l}\text { Oxygen consumption that persists due to a subset of cellular enzymes that } \\
\text { continue to consume oxygen after the addition of rotenone and antimycin A. } \\
\text { This is important to get an accurate measure of mitochondrial respiration. }\end{array}$ & $\begin{array}{l}\text { Minimum rate measurement after } \\
\text { Rotenone/antimycin A injection }\end{array}$ \\
\hline $\begin{array}{l}\text { Coupling } \\
\text { efficiency }\end{array}$ & Loss of proton-motive force due to proton leak & $\begin{array}{l}\text { (ATP Production Rate) / (Basal Respiration } \\
\text { Rate) } \times 100\end{array}$ \\
\hline
\end{tabular}


Fig. 7. Mitochondrial stress test. (A) Time course of OCR measurement using the indicated inhibitors. The rate signal is shown normalized to timepoint 3 before Oligomycin was applied. (B) Proton leak differs significantly in old and very old cells. (C) Spare capacity and coupling efficiency increase significantly in old and very old cells. A and b depict significantly different groups. Error bars denote mean values \pm SEM; $\mathrm{n}=3$.

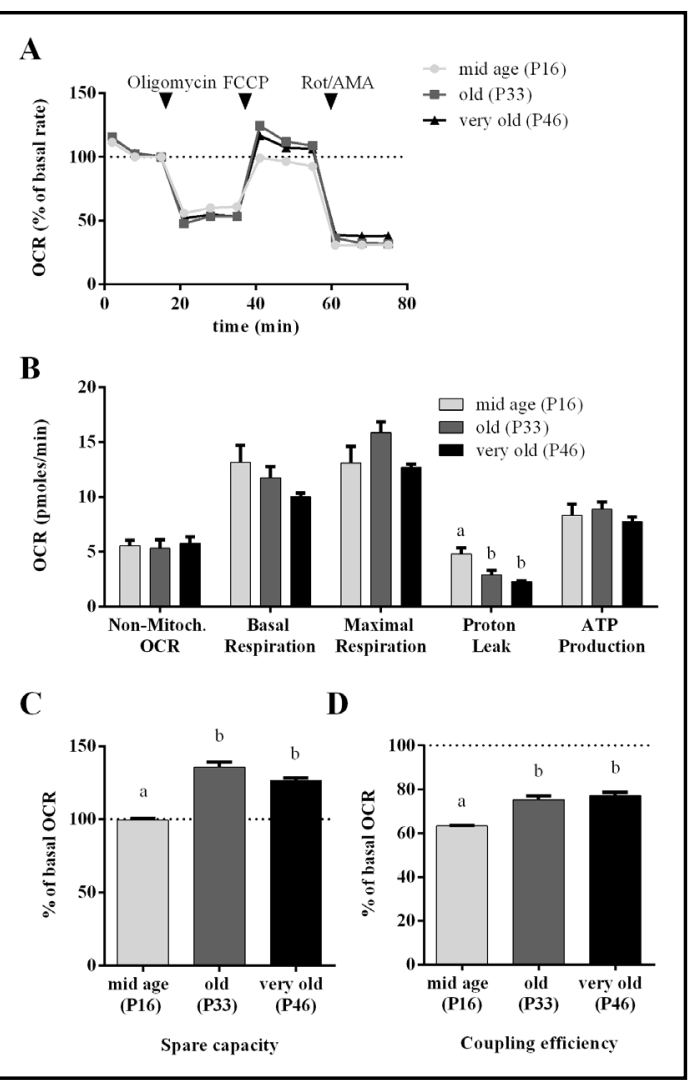

Fig. 8. Comparison of energy phenotypes of mid age, old and very old Z3 cells. OCR and ECAR were extracted from mitochondrial stress tests where basal rates and stressed rates correspond to timepoints 3 and 7 (oligomycin and FCCP present), respectively. Under energy stress all age groups increase their glycolytic output whereas only old and very old cells appear to be able to increase their mitochondrial capacity as well. Error bars denote mean values \pm SEM; $n=3$.

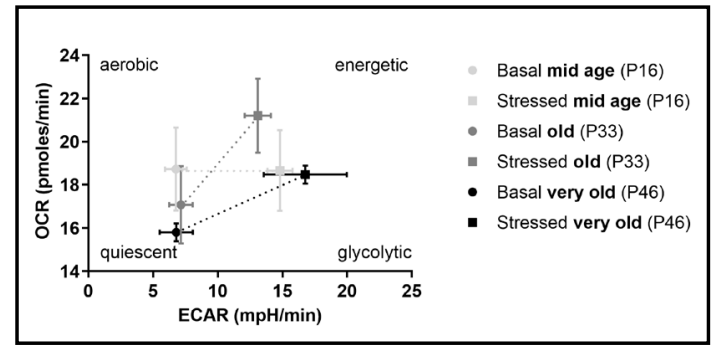

Table 2. Overview of measured parameters in cell passages that have been categorized into four age groups. Results are summarized by presenting significance letters according to the results figures. The group of young cells have been used as starting point to indicate the up- or downward trend of the results no difference (--), up-regulation $(\uparrow)$, down-regulation $(\downarrow)$

\begin{tabular}{lcccc}
\hline Parameter & $\begin{array}{c}\text { young } \\
(1-10)\end{array}$ & $\begin{array}{c}\text { mid age } \\
(11-25)\end{array}$ & $\begin{array}{c}\text { old } \\
(26-37)\end{array}$ & $\begin{array}{c}\text { very old } \\
(38-49)\end{array}$ \\
\hline Pyruvate & $\mathrm{a}-$ & $\mathrm{b} \downarrow$ & $\mathrm{b} \downarrow$ & $\mathrm{b} \downarrow$ \\
Proton leak & & $\mathrm{a}--$ & $\mathrm{b} \downarrow$ & $\mathrm{b} \downarrow$ \\
DNA damage $\left(100 \mu \mathrm{M} \mathrm{H}_{2} \mathrm{O}_{2}\right)$ & $\mathrm{a}-$ - & $\mathrm{a}--$ & & $\mathrm{b} \downarrow$ \\
Growth rate & $\mathrm{a}--$ & $\mathrm{ab}--$ & $\mathrm{ab}--$ & $\mathrm{b} \downarrow$ \\
Redox state (Lactate:Pyruvate) & $\mathrm{a}--$ & $\uparrow$ & $\uparrow \uparrow$ & $\uparrow \uparrow \uparrow$ \\
p53 & $\mathrm{a}--$ & $\mathrm{b} \uparrow$ & $\mathrm{a}--$ & $\mathrm{a}--$ \\
Beta gal activity & $\mathrm{a}--$ & $\mathrm{a}--$ & $\mathrm{b} \uparrow$ & $\mathrm{b} \uparrow$ \\
Coupling efficiency & & $\mathrm{a}--$ & $\mathrm{b} \uparrow$ & $\mathrm{b} \uparrow$ \\
Spare capacity & & $\mathrm{a}--$ & $\mathrm{b} \uparrow$ & $\mathrm{b} \uparrow$ \\
DNA damage $\left(10 \mu \mathrm{M} \mathrm{H}_{2} \mathrm{O}_{2}\right)$ & $\mathrm{a--}$ & $\mathrm{a}--$ & & $\mathrm{b} \uparrow$ \\
DNA damage $\left(1 \mu \mathrm{M} \mathrm{H}_{2} \mathrm{O}_{2}\right)$ & & $\mathrm{a}--$ & & $\mathrm{b} \uparrow$ \\
DNA damage without $\mathrm{H}_{2} \mathrm{O}_{2}$ treatment & $\mathrm{a}--$ & $\mathrm{a}--$ & & $\mathrm{b} \uparrow$ \\
Lactate & $\mathrm{a}--$ & $\mathrm{a}--$ & $\mathrm{b} \uparrow$ & $\mathrm{a}-$ \\
Non-glycolytic ECAR & & $\mathrm{ab}--$ & $\mathrm{a}--$ & $\mathrm{b} \uparrow$ \\
Glycolytic reserve & & $\mathrm{a}--$ & $\mathrm{a}--$ & $\mathrm{b} \uparrow$ \\
Maximum respiration & & -- & -- & -- \\
Basal respiration & & -- & -- & -- \\
Glycolytic capacity & & -- & -- & -- \\
Catalase & -- & -- & -- & -- \\
HIFs & -- & -- & -- & -- \\
Glycolysis & & -- & -- & -- \\
Non-mitochondrial OCR & & -- & -- & -- \\
ATP production & & -- & -- & -- \\
\hline
\end{tabular}




\section{HIF protein expression}

Since longevity has been linked to hypoxia and therefore also the hypoxia inducible factor (HIF), we determined HIF1 and HIF3 protein levels, which did not change in different cell passages (Fig. 9).

\section{Multidimensional scaling (MDS) or Principal Co-ordinate analysis}

MDS analysis was performed on 8 variables (beta-gal activity, p53, DNA damage, lactate, pyruvate, catalase, HF1, HF3) and passage numbers 5, 9, 15 (young), 19, 25 (mid aged), 31, 36 (old), 40, 45, 50 (very old cells). This dataset encompassed those analyses that were performed on most passage numbers. Significant separation between cell passages based on age class was observed in both MDS dimensions. In MDS1 young and old cells were significantly separated from very old cells and in MDS2 young and mid-aged cells cells separated significantly from old cells. It is evident that young and mid-aged cells group closely together, whereas old and very old cells are more spread out, pointing to the inconsistent response (Fig. 10).

Fig. 9. HIF1 and HIF3 protein expression did not significantly change in different cell passages. Error bars denote mean values \pm SEM; $n=3$ to 4 . For HIF1 in passage 40 , as indicated, only two biological replicates have been processed.
Fig. 10. MDS analysis on 8 variables (beta-gal, p53, DNA damage, lactate, pyruvate, catalase, HF1, HF3) and passage numbers 5,9,15 (young), 19,25 (mid aged), 31,36 (old), 40,45,50 (very old cells). Significant separation between groups in MDS_1 based on an age class $(\mathrm{p} \geq 0.000628$, ANOVA; posthoc Tukey: young (a), mid-aged (ab), old (a), very old (b)). Significant separation between groups in MDS_2 based on an age class ( $\mathrm{p} \geq 0.00456$, ANOVA; posthoc Tukey: young (a), mid-aged (a), old (b), very old (ab)). Stress level (goodness of a fit is 0.05 , between excellent and good fit).
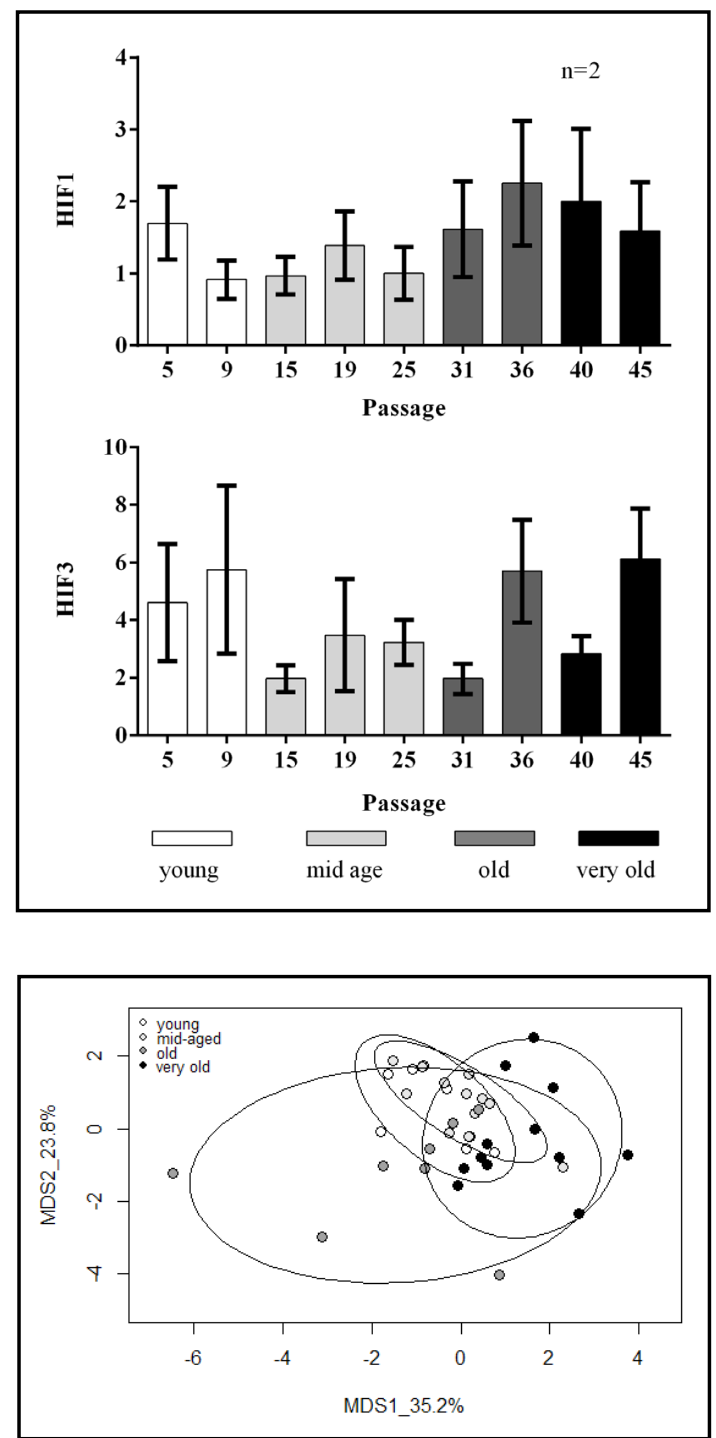


\section{Cellular Physiology Cell Physiol Biochem 2022;56:50-65 \\ \begin{tabular}{ll|l} 
and Biochemistry & $\begin{array}{l}\text { DOI: 10.33594/000000494 } \\
\text { Published online: } 9 \text { February } 2022\end{array}$ & $\begin{array}{l}\text { C } 2022 \text { The Author(s). Published by } \\
\text { Cell Physiol Biochem Press GmbH\&Co. KG }\end{array}$
\end{tabular} \\ Šrut et al.: Aging Cell Culture}

\section{Discussion}

Cell lines are widely used in biomedical research. Zebrafish fibroblast cells are common models for a variety of research topics. The effect of passage numbers on physiological and genetic parameters is, however, often underestimated. We therefore analyzed the effects of cell passage number on a variety of end points and showed significant age-related differences in the zebrafish embryonic fibroblast cell line Z3.

First, we examined the degree of cellular senescence, which was, as mentioned earlier, originally referred to as the replicative limit of cell cultures and was recently suggested to define senescence as "state of stress-induced irreversible proliferative arrest and resistance to both mitogenic and oncogenic stimuli" [14]. We used beta-gal activity as biomarker to determine cellular senescence. A study in human fibroblast cell lines showed that betagal activity is negatively correlated with the speed of growth rather than the chronological age [23]. Increased beta-gal activity could also be indicative of lysosomal stress - the detection of proliferative arrest is yet inconclusive and it was suggested that more than one senescence marker should be used [14]. We grouped the results of beta-gal activity into no signal, stage 1 (slight stain), and stage 2 (intense stain) and observed a significant increase of stage 1 cells from passage 31 until 50 indicating that Z3 cells might show very early stages of senescence. The doubling time of Z3 cells did not show a significant correlation to passage numbers. When we grouped the passages, the doubling time of the oldest group decreased significantly compared to the youngest, however, no replicative arrest was observed in our experiments until passage 49. In a similar study on D1 cells it was shown that the growth rate slowed down after passage 30 [3]. Bet hedging strategies, which are applied to increase survival chances under stressful conditions and are related to the replicative age in yeast show that slow growth rates are correlated with higher resistance to stress [24].

Usually, senescence starts from a reversible phase with high p53 activity, then proceeding to permanent cell cycle arrest [25]. p53 promotes cell survival by an antioxidative effect, however, when stress levels are too high p53 has a pro-oxidant effect that leads to apoptosis and senescence $[26,27]$. Just prior to the increase of beta-gal activity levels, we detected significantly increased p53 mRNA levels in passage 19 and 25, which decreased again in older cells. In human epithelial cells, p53 decreased in an age-related manner [28]. p53 is an important regulator of DNA repair mechanisms to maintain genomic stability [29]. Considering that DNA damage presents the main driver of aging [30], we also determined the degree of DNA strand breaks. DNA damage showed elevated levels in passage 40, which is opposing to p53 levels and could explain the increased DNA damage. It has been previously demonstrated that older cells tend to accumulate higher amount of DNA damage. For instance, primary lung fibroblasts cultured from older mice showed higher basal DNA damage in comparison to those cultured from younger mice [31]. Significant increase in spontaneous DNA damage with age has been also demonstrated in normal mouse liver cells [32]. It is considered that during the normal aging process, DNA damage may gradually rise as a consequence of higher genotoxic stress or malfunctioning of genome maintenance [32].

Aging has been linked to lower DNA repair capacity under oxidative stress [33] and oxidative damage is, however, considered the major damage of macromolecules during the aging process [34]. Human embryonic lung fibroblast cells exposed to serial dilutions of $\mathrm{H}_{2} \mathrm{O}_{2}$ during the aging process showed higher induction of DNA damage at all concentrations tested in older cells and as the aging progressed the cells accumulated more damage due to imposed oxidative stress [33]. Similarly, in human WI-38 fibroblast cells, DNA damage induced by $\mathrm{H}_{2} \mathrm{O}_{2}$ in old cells, reflected increased susceptibility to oxidative damage as well as reduced efficiency of the DNA repair system [35]. Our results follow the same trend and older zebrafish cells exhibited higher induction of DNA damage. $\mathrm{H}_{2} \mathrm{O}_{2}$-induced DNA damage in passage 40 , however, is slightly reduced compared to younger cells.

This age-dependent sensitivity to ROS is not reflected in changes to the cellular redox systems we studied in these cells. First, the amount of catalase, which is responsible for $\mathrm{H}_{2} \mathrm{O}_{2}$ degradation, did not change between age groups. Second, it has recently been shown that a 


\section{Cellular Physiology Cell Physiol Biochem 2022;56:50-65

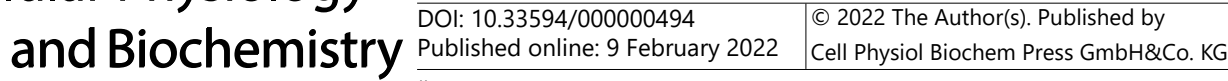 \\ Šrut et al.: Aging Cell Culture}

considerable portion of the ECAR of $\mathrm{Z3}$ cells derives from $\mathrm{CO}_{2}$ from the pentose phosphate pathway (PPP) [36], which is the main recycler of the redox currency NADPH. Since the basal ECAR of cells supplied with glucose did not significantly change between the different age groups (Fig. 6) we hypothesize that also the contribution from the PPP, and therefore its NADP+ reducing activity is not changing. However, one should keep in mind that the PPP can run in different modes with different net $\mathrm{CO}_{2}$ production. The increased sensitivity to oxygen radicals with cellular age may have other causes. In general, Z3 cells reveal a high sensitivity to $\mathrm{H}_{2} \mathrm{O}_{2}$ with recorded levels of around 70\% tDNA upon exposure to $10 \mu \mathrm{mol}$ $\mathrm{H}_{2} \mathrm{O}_{2}$. In comparison, mussel haemocytes, anlysed with the exact same methodical approach, showed less than 5\% DNA damage applying the same conditions [37]. We hypothesize that one important radical scavenger, metallothionein 1, which is not expressed in Z3 cells could lead to a higher susceptibility to oxidative stress [38].

Moreover, p53 is also known to regulate the central carbon metabolism dampening aerobic glycolysis in favor of oxidative phosphorylation [39]. p53 drives the production of acetyl-CoA while decreasing lactate levels [40]. In the present study, when p53 gene expression was increased in the mid age group, we did not observe changes in basal glycolysis rates or detect differences in lactate levels. Generally it is known, that increased lactate levels protect cells from mitochondrial dysfunction, lead to an improved quality control by autophagy and less cells that undergo senescence [41]. Lactate has the potential to regulate the cellular redox state. It is also capable of mimicking a state of lacking $\mathrm{O}_{2}$ for example in wound healing, which is important for neovascularization [42].

We found a slightly higher basal respiration compared to the older groups that also had very low p53 gene expression. This slight reduction in basal OCR in older age groups fits to our observation of a continuous shift in aging cells to a reduced cellular redox state as shown from the NAD+/NADH ratio calculated from pyruvate:lactate levels. A study in senescent human and mouse fibroblasts found decreased levels of NAD+/NADH [43] and also in aging rats it was shown that the NAD+/NADH ratio decreased [44]. A recent study using cell models with different levels of mitochondrial dysfunction describes impaired utilization of reduced nicotinamide dinucleotide (NADH) [45]. We conclude that with increasing passage numbers mitochondrial respiration declines giving rise to alterations in the cytosolic NAD+/ NADH balance.

Moreover, p53 inhibits glucose uptake by down-regulation of glucose transporters [46]. Metabolic measurements revealed that glycolysis did not change in Z3 cells of different passage groups. However, glycolytic reserve as well as mitochondrial spare capacity did significantly change between the different cell passages. We therefore conclude that higher passage numbers show an increased metabolic capacity (respiratory and glycolytic). A significant decrease in proton leak and increased coupling efficiency supports this hypothesis.

There is a known link between longevity and hypoxia, which includes the hypoxia inducible factor HIF-1 $[47,48]$. However, opposing results in C. elegans studies showed that the stabilization as well as the deletion of HIF-1 leads to an increased life span [49]. Herein HIF-1 as well as HIF-3 protein expression did not change.

Our data indicate several parameters as good indicators that show cell response based on age. The parameters that showed the most dramatic changes in Z3 cells include betagal activity, p53 transcription levels, DNA damage, cellular redox state, glycolytic reserve, spare capacity, and coupling efficiency. Therefore, those parameters are suggested as useful toolkit for other research groups to determine cellular response based on age. Principal Component Analysis performed on a very small data set due to some missing values revealed, however, a significant separation mainly based on beta-gal activity and lactate levels in the first dimension as shown in Supplementary Fig. S1 (for all supplementary material see www.cellphysiolbiochem.com). On the other hand, parameters such as catalase, glycolysis, glycolytic capacity, non-Mito OCR, basal and maximum respiration rate, ATP production, and HIFs did not show any significant changes and can be considered as poor indicators of cellular fitness regarding age. 


\section{Cellular Physiology Cell Physiol Biochem 2022;56:50-65 \\ \begin{tabular}{l|l|l}
\hline DOI: 10.33594/000000494 & (c) 2022 The Author(s). Published by
\end{tabular} \\ \begin{tabular}{l|l} 
Published online: 9 February 2022 & Cell Physiol Biochem Press GmbH\&Co. KG \\
\hline
\end{tabular} \\ Šrut et al.: Aging Cell Culture}

MDS analysis performed on eight parameters revealed significant separation between four age categories of Z3 cells. This clearly indicates that passage number has a significant effect on the physiology of the Z3 cell line. Young and mid-aged cells grouped closely together and showed a more unique response of the analyzed parameters, whereas old and very old cells exhibited a more dispersed and inconsistent response. Therefore, to minimize variability and increase reproducibility of the experiments, researchers working with Z3 cells are encouraged to use cells between 5 and 15 passages, after which the culture should be renewed. After passage 15, we could show that drastic changes in p53 levels occurred, and pyruvate levels dropped significantly.

\section{Conclusion}

In conclusion, since we found a wide range of differences between passage numbers, we would suggest testing several cell passages before running an experiment to exclude agerelated effects in cell lines. It is therefore necessary to use as consistent passage numbers as possible to obtain reliable, accurate, and reproducible data. Furthermore, researchers working with cell lines are encouraged to test the age-related differences in various passages using some of the suggested parameters that changed the most like beta-gal activity, p53 transcription levels, DNA damage, cellular redox state, glycolytic reserve, spare capacity, and coupling efficiency.

Multivariate analyses can also be useful tools to determine the intra and inter variability in cell age classes and can indicate the range of cell passages which are the most consistent in response and should be used in experiments.

\section{Highlights}

- Very old cells show an increased level of basal DNA damage.

- Higher passage numbers show an increased metabolic capacity.

- A continuous shift in aging cells to a reduced cellular redox state can be observed.

- Young and mid-aged cells cluster together and show more similarity to very old rather than old cells.

- Non-linear effects of several physiological parameters have been observed from cells of different passage numbers.

\section{Acknowledgements}

We thank Lorenz Spechtenhauser for his contribution to literature search and Scarlett Treml for her contribution to the lab work.

\section{Author Contributions}

MS Investigation, Writing - Original Draft, Review and Editing; BP Investigation; BF Investigation; ME Conceptualisation, Writing - Review and Editing; AS Investigation, Formal analysis, Writing - Review and Editing; MH Visualization, Conceptualization, Formal analysis, Writing - Original Draft, Review and Editing.

\section{Disclosure Statement}

The authors declare that no conflicts of interest exist. 


\section{Cellular Physiology Cell Physiol Biochem 2022;56:50-65 \begin{tabular}{l|l|l} 
DOI: 10.33594/000000494 & 2022 The Author(s). Published by
\end{tabular} and Biochemistry Published online: 9 February 2022 Cell Physiol Biochem Press GmbH\&Co. KG \\ Šrut et al.: Aging Cell Culture}

\section{References}

1 Pouliott C, Dupuis M, Appler K, Brunt S, Rudd R, Davis A: Susceptibility of neuroblastoma cells to rabies virus may be affected by passage number. J Virol Methods 2017;247:28-31.

2 Pronsato L, La Colla A, Ronda AC, Milanesi L, Boland R, Vasconsuelo A: High passage numbers induce resistance to apoptosis in C2C12 muscle cells. Biocell 2013;37:1-9.

3 Kwist K, Bridges WC, Burg KJL: The effect of cell passage number on osteogenic and adipogenic characteristics of D1 cells. Cytotechnology 2016;68:1661-1667.

4 Mouriaux F, Zaniolo K, Bergeron MA, Weidmann C, De La Fouchardière A, Fournier F, Droit A, Morcos MW, Landreville S, Guérin SL: Effects of long-term serial passaging on the characteristics and properties of cell lines derived from uveal melanoma primary tumors. Investig Ophthalmol Vis Sci 2016;57:5288-5301.

5 Mohammadi Farsani T, Motevaseli E, Neyazi N, Khorramizadeh MR, Zafarvahedian E, Ghahremani MH: Effect of Passage Number and Culture Time on the Expression and Activity of Insulin-Degrading Enzyme in Caco-2 Cells. Iran Biomed J 2018;22:70-75.

6 Senarathna SMDKG, Crowe A: The influence of passage number for Caco 2 cell models when evaluating P-gp mediated drug transport. Pharmazie 2015;70:798-803.

7 Hughes P, Marshall D, Reid Y, Parkes H, Gelber C: The costs of using unauthenticated, over-passaged cell lines: How much more data do we need? Biotechniques 2007;43:575-586.

8 Wenger SL, Senft JR, Sargent LM, Bamezai R, Bairwa N, Grant SG: Comparison of established cell lines at different passages by karyotype and comparative genomic hybridization. Biosci Rep 2004;24:631-639.

9 Inzunza J, Sahlén S, Holmberg K, Strömberg AM, Teerijoki H, Blennow E, Hovatta O, Malmgren H: Comparative genomic hybridization and karyotyping of human embryonic stem cells reveals the occurrence of an isodicentric X chromosome after long-term cultivation. Mol Hum Reprod 2004;10:461466.

10 Xie X, Hiona A, Lee AS, Cao F, Huang M, Li Z, Cherry A, Pei X, Wu JC: Effects of long-term culture on human embryonic stem cell aging. Stem Cells Dev 2011;20:127-138.

11 Mitalipova MM, Rao RR, Hoyer DM, Johnson JA, Meisner LF, Jones KL, Dalton S, Stice SL: Preserving the genetic integrity of human embryonic stem cells. Nat Biotechnol 2005;23:19-20.

12 Cao J, Wu X, Qin X, Li Z: Uncovering the Effect of Passage Number on HT29 Cell Line Based on the Cell Metabolomic Approach. J Proteome Res 2021;20:1582-1590.

13 Gilbert SF: Aging: The Biology of Senescence. Developmental Biology. Sunderland (MA), Sinauer Associates, 2000, ed 6. URL: https://www.ncbi.nlm.nih.gov/books/NBK10041/.

14 Sharpless NE, Sherr CJ: Forging a signature of in vivo senescence. Nat Rev Cancer 2015;15:397-408.

15 Pando MP, Pinchak AB, Cermakian N, Sassone-Corsi P: A cell-based system that recapitulates the dynamic light-dependent regulation of the vertebrate clock. Proc Natl Acad Sci U S A. 2001;98:10178-10183.

16 Hirayama J, Cardone L, Doi M, Sassone-Corsi P: Common pathways in circadian and cell cycle clocks: Light-dependent activation of Fos/AP-1 in zebrafish controls CRY-1a and WEE-1. Proc Natl Acad Sci 2005;102:10194-10199.

17 Kopp R, Köblitz L, Egg M, Pelster B: HIF signaling and overall gene expression changes during hypoxia and prolonged exercise differ considerably. Physiol Genomics 2011;43:506-516.

18 Singh NP, McCoy MT, Tice RR, Schneider EL: A simple technique for quantitation of low levels of DNA damage in individual cells. Exp Cell Res 1988;175:184-191.

19 Koñca K, Lankoff a, Banasik a, Lisowska H, Kuszewski T, Góźdź S, Koza Z, Wojcik A: A cross platform public domain PC image analysis program for the comet assay. Mutat Res 2003;534:15-20.

20 R Core Team: R: A languabe and Environment for statistical computing. R Foundation for Statistical Computing, Vienna, Austria, 2020. URL: https://www.eea.europa.eu/data-and-maps/indicators/oxygenconsuming-substances-in-rivers/r-development-core-team-2006.

21 Sun F, Dai C, Xie J, Hu X: Biochemical Issues in Estimation of Cytosolic Free NAD/NADH Ratio. PLoS One 2012;7:e34525.

22 Sandbichler AM, Jansen B, Peer BA, Paulitsch M, Pelster B, Egg M. Metabolic Plasticity Enables Circadian Adaptation to Acute Hypoxia in Zebrafish Cells. Cell Physiol Biochem 2018;46:1159-1174.

23 Maier AB, Westendorp RGJ, Van Heemst D: $\beta$-Galactosidase activity as a biomarker of replicative senescence during the course of human fibroblast cultures. Ann N Y Acad Sci 2007;1100:323-332. 


\section{Cellular Physiology Cell Physiol Biochem 2022;56:50-65 \begin{tabular}{c|c|c|c|}
\hline DOI: 10.33594/000000494 2022 The Author(s). Published by \\
\hline
\end{tabular} and Biochemistry Published online: 9 February 2022 Cell Physiol Biochem Press GmbH\&Co. KG \\ Šrut et al.: Aging Cell Culture}

24 Levy SF, Ziv N, Siegal ML: Bet Hedging in Yeast by Heterogeneous, Age-Correlated Expression of a Stress Protectant. PLoS Biol 2012;10:e1001325.

25 James EL, Michalek RD, Pitiyage GN, De Castro AM, Vignola KS, Jones J, Mohney RP, Karoly ED, Prime SS, Parkinson EK: Senescent Human Fibroblasts Show Increased Glycolysis and Redox Homeostasis with Extracellular Metabolomes That Overlap with Those of Irreparable DNA Damage, Aging, and Disease. J Proteome Res 2015;14:1854-1871.

26 Liu B, Chen Y, St Clair DK: ROS and p53: A versatile partnership. Free Radic Biol Med 2008;44:1529-1535.

27 Vousden KH, Prives C: Blinded by the Light: The Growing Complexity of p53. Cell 2009;137:413-431.

28 Wu D, Prives C: Relevance of the p53-MDM2 axis to aging. Cell Death Differ 2018;25:169-179.

29 Nicolai S, Rossi A, Di Daniele N, Melino G, Annicchiarico-Petruzzelli M, Raschellà G: DNA repair and aging: the impact of the p53 family. Aging (Albany NY) 2015;7:1050-1065.

30 Moskalev AA, Shaposhnikov M V., Plyusnina EN, Zhavoronkov A, Budovsky A, Yanai H, Fraifeld VE: The role of DNA damage and repair in aging through the prism of Koch-like criteria. Ageing Res Rev 2013;12:661684.

31 López-Diazguerrero NE, Luna-López A, Gutiérrez-Ruiz MC, Zentella A, Königsberg M: Susceptibility of DNA to oxidative stressors in young and aging mice. Life Sci 2005;77:2840-2854.

32 Maslov AY, Ganapathi S, Westerhof M, Quispe-Tintaya W, White RR, Van Houten B, Reiling E, Dollé MET, van Steeg H, Hasty P, Hoeijmakers JHJ, Vijh G: DNA damage in normally and prematurely aged mice. Aging Cell 2013;12:467-77.

33 Wang JL, Wang PC: The effect of aging on the DNA damage and repair capacity in 2BS cells undergoing oxidative stress. Mol Biol Rep 2012;39:233-241.

34 Van Meter M, Simon M, Tombline G, May A, Morello TD, Hubbard BP, Bredbenner K, Park R, Sinclair DA, Bohr VA, Gorbunova V, Seluanov A: JNK Phosphorylates SIRT6 to Stimulate DNA Double-Strand Break Repair in Response to Oxidative Stress by Recruiting PARP1 to DNA Breaks. Cell Rep 2016;16:2641-2650.

35 Wolf FI, Torsello A, Covacci V, Fasanella S, Montanari M, Boninsegna A, Cittadini A: Oxidative DNA damage as a marker of aging in WI-38 human fibroblasts. Exp Gerontol 2002;37:647-656.

36 Dikova V, Vorhauser J, Geng A, Pelster B, Sandbichler AM: Metabolic interaction of hydrogen peroxide and hypoxia in zebrafish fibroblasts. Free Radic Biol Med 2020;152:469-481.

37 Štambuk A, Pavlica M, Malović L, Klobučar GIV: Persistence of DNA damage in the freshwater mussel Unio pictorum upon exposure to ethyl methanesulphonate and hydrogen peroxide. Environ Mol Mutagen 2008;49:217-225.

38 Sandbichler AM, Höckner M: Cadmium Protection Strategies--A Hidden Trade-Off? Int J Mol Sci 2016;17:139.

39 Berkers CR, Maddocks ODK, Cheung EC, Mor I, Vousden KH: Metabolic regulation by p53 family members. Cell Metab 2013;18:617-633.

40 Contractor T, Harris CR: p53 negatively regulates transcription of the pyruvate dehydrogenase kinase Pdk2 Cancer Res 2012;72:560-567.

41 Zelenka J, Dvořák A, Alán L: L-Lactate protects skin fibroblasts against aging-Associated mitochondrial dysfunction via mitohormesis. Oxid Med Cell Longev 2015;2015:351698.

42 Philp A, Macdonald AL, Watt PW: Lactate - a signal coordinating cell and systemic function. J Exp Biol 2005;208:4561-4575.

43 Yu DM, Jung SH, An HT, Lee S, Hong J, Park JS, Lee H, Lee H, Bahn MS, Lee HC, Han NK, Ko J, Lee JS, Ko YG: Caveolin-1 deficiency induces premature senescence with mitochondrial dysfunction. Aging Cell 2017;16:773-784.

44 Braidy N, Guillemin GJ, Mansour H, Chan-Ling T, Poljak A, Grant R: Age related changes in NAD+ metabolism oxidative stress and Sirt1 activity in wistar rats. PLoS One 2011;6:e19194.

45 Gaude E, Schmidt C, Gammage PA, Dugourd A, Blacker T, Chew SP, Saez-Rodriguez J, O’Neill JS, Szabadkai G, Minczuk M, Frezza C: NADH Shuttling Couples Cytosolic Reductive Carboxylation of Glutamine with Glycolysis in Cells with Mitochondrial Dysfunction. Mol Cell 2018;69:581-593.e7.

46 Schwartzenberg-Bar-Yoseph F, Armoni M, Karnieli E: The Tumor Suppressor p53 Down-Regulates Glucose Transporters GLUT1 and GLUT4 Gene Expression. Cancer Res 2004;64:2627-2633.

47 Mehta R, Steinkraus KA, Sutphin GL, Ramos FJ, Shamieh LS, Huh A, Davis C, Chandler-Brown D, Kaeberlein M: Proteasomal Regulation of the Hypoxic Response Modulates Aging in C. elegans. Science 2009;324:1196-1198. 
Cellular Physiology Cell Physiol Biochem 2022;56:50-65

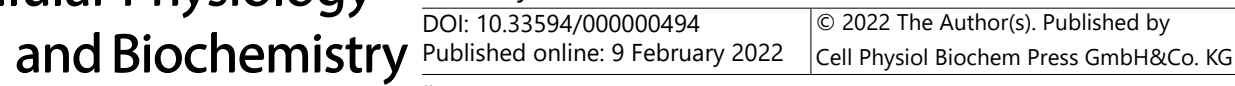

Šrut et al.: Aging Cell Culture

48 Poulios E, Trougakos IP, Chondrogianni N, Gonos ES: Exposure of human diploid fibroblasts to hypoxia extends proliferative life span. Ann N Y Acad Sci 2007;1119:9-19.

49 Leiser SF, Kaeberlein M: The hypoxia-inducible factor HIF-1 functions as both a positive and negative modulator of aging. Biol Chem 2010;391:1131-1137. 